\title{
Academic work from a comparative perspective: A survey of faculty working time across 13 countries
}

Peter Bentley \& Svein Kyvik

Nordic Institute for Studies in Innovation, Research and Education;

Wergelandsveien 7, N-0167, Oslo, Norway.

Email: pbentley@unimelb.edu.au \& svein.kyvik@nifu.no

Tel: (+47) 22595100

Fax: (+47) 22595101

\begin{abstract}
Sociological institutional theory views universities as model driven organizations. The world's stratification system promotes conformity, imitation and isomorphism towards the "best" university models. Accordingly, academic roles may be locally shaped in minor ways, but are defined and measured explicitly in global terms. We test this proposition using data on the allocation of working time between academic tasks at research universities in thirteen countries: Argentina, Australia, Brazil, Canada, China, Finland, Germany, Hong Kong, Italy, Malaysia, Norway, UK, and the USA. We find that working time patterns differ significantly across countries, suggesting that conditions of academic work remain heavily dependent on national higher education traditions. Faculty members holding the highest professorial rank share more in common, with generally stronger interests in research and a greater time dedication to research over teaching. However, in countries with comparably steep academic hierarchies, professor positions typically entail significantly fewer teaching hours and more administration.
\end{abstract}

Keywords: higher education, academic profession, working time, workloads, isomorphism.

The final, definitive version of this paper has been published in Higher Education Higher Education, 63(4), pp. 529-547 by Springer. [ http://link.springer.com/article/10.1007\%2Fs10734011-9457-4 ] 


\section{Introduction}

North America, Europe and emerging Asian countries stand on the brink of a postindustrial knowledge society. The modern research university - with its teaching, research and service missions - stands as the pivotal institution because it produces knowledge (research), and transmits knowledge to students (teaching) and to societal stakeholders (service) (Scott 2006). Internationalization has brought about a worldwide convergence in the mission complexity of universities, and in an overview of challenges to the faculty in many countries, Welch (2005) notes that there seems to be a pressure to do more with fewer resources and difficulty in meeting multiple research, teaching and administrative responsibilities, as each component has become more demanding. Traditional self-determination and autonomy over faculty working times has come under increasing scrutiny as universities around the world have faced calls for improved productivity, efficiency and accountability. Faculty still consider themselves as independent professionals, but management discretion has grown relative to academic autonomy in many countries, leaving academics as increasingly "managed professionals” (Rhoades 1997; Slaughter and Leslie 1997). Yet, we know relatively little about the extent to which the emphasis on various missions and work tasks differ between countries.

Former studies undertaken in different countries show that there are large differences between individual faculty members in research universities in how they spend their working time (see e.g. Altbach 1996). There is also ample evidence of differences in working time patterns between universities within a single country (see e.g. Milem et al. 2000, Schuster and Finkelstein 2006). But while the distribution of working time has been examined by many individual universities and in many countries, cross-country comparative studies are in short supply. The Carnegie study of the international academic profession undertaken in 1992-93 included questions on working time, but the results were insufficiently analyzed (Altbach 1996). Based on that study, Enders and Teichler (1997) show evidence of cross-national differences in the allocation of time in research universities across countries, but their findings are affected by the inclusion of faculty members with different temporal employment contracts (e.g. part-time faculty) and duties classifications (e.g. teaching-only and research-only faculty). Thus, the issue of national similarities and differences in faculty working time is not yet fully examined.

The purpose of this study is to compare national aggregates of individual working time patterns of faculty in universities with similar research missions in a selection of countries across the globe. To ensure national differences in the extent of non-standard academic employment do not skew cross-national comparisons, this study examines differences in working time patterns of full-time faculty in combined teaching and research positions.

Our analytical approach is drawn from sociological institutional theory. In their seminal paper on higher education as an institution, Meyer et al. (2007) use such a perspective to interpret change in educational systems, structures and contents. They argue that the nature and meaning of higher education has been institutionalized over a very long period of time and now applies commonly throughout the world. This implies that the meaning of categories such as university or professor "may be locally shaped in minor ways but at the same time have very substantial historical and global standing. These wider meanings obviously have pervasive impacts on the content and character of local settings" (Meyer et al. 2007, 187). Furthermore, "universities and colleges, together with their disciplinary fields and academic roles, are defined, measured, and instantiated in essentially every country in explicitly global terms” (Meyer et al. 2007, 188).

As universities compete in their ranking vis-à-vis all others, institutional theory predicts isomorphic change towards the practice of the most successful institutions. In the USA, there is 
some evidence of this process, as institutions with different research and teaching missions have become increasingly similar in their faculty working time patterns (Milem et al. 2000). There are also good reasons to assume that this process is taking place across the globe. This theoretical approach is concerned with the diffusion of ideas and practice from countries possessing a cultural hegemony to the rest of the world, and the subsequent institutionalization of similar organizational structures, rules and norms across countries. An underlying assumption is that universities and their faculty in other countries will try to emulate the research and teaching practices of research universities in the English-speaking world, including the working conditions of academic staff. Faculty members collaborate increasingly with colleagues in other countries, preferably in the leading research nations, they have sojourns at universities abroad, and norms for good professorial practice and working conditions are effectively spread.

Based on this theoretical approach we have put forward some hypotheses that can be tested. First, at this stage in the historic development of research universities differences in working time patterns across countries should be relatively small. The academic world is hierarchic, with AngloAmerican research universities setting the standards and practices to which institutional isomorphism suggests the rest of the world will follow. The purposeful management of universities based on standardized ranking scales de-emphasizes horizontal differences and diversity in institutional mission (Marginson 2007). Performance management of faculty, as well as institutions, has been implemented across a range of countries. Such practices have reduced self-determination over how academics divide their time between teaching and research (Enders and Musselin 2008).

Second, differences in working time patterns should be smallest between English-speaking countries and those culturally close to the English-speaking world. According to Enders and Musselin (2008), the effects of internationalization varies across countries based on the dominance of the national higher education system, economy, geography, culture, language and integration with the international center of the academic world. The size, power and economic success of the USA guarantees a worldwide influence and elements of the American research university model have been exported to many countries across the globe (Jones 1992). Academics in the USA, and to a lesser extent the UK, are comfortably placed in the center of the internationalization process, acting primarily as hosts to foreign academics and enjoying hegemony over the language that defines international research and reputation (Enders and Musselin 2008). Faculty in large, nonEnglish speaking countries with strong higher education traditions may also be relatively insular in their outlook, due to large domestic research audiences. By contrast, international networks are indispensible to academics in small and peripheral countries.

Third, because the notion of full professor is common across countries, we expect working time patterns to be most similar between faculty sharing the highest professor rank. Institutional theory contends that the professionalization and structure of the academic career supports "normative isomorphism" as one approaches the highest rank of professor (DiMaggio and Powell 1983). The academic profession contains codes of conduct and common socialization patterns, from the entry level to full professor, which operate as a filter for career progression. Individuals with the highest rank share a common set of attributes and approaches to work that are normatively sanctioned and legitimated. Throughout their career, professors observe a common pattern of time allocated by other faculty, which is mimicked and reinforced by the academic socialization and reward systems (Milem et al. 2000, 472).

The results of this study should be of theoretical as well as practical interest. Theoretically, the study examines to what extent institutional theory can provide a basis for explaining similarities and differences in academic practice across countries. Practically, the study provides useful 
information to policy-makers, institutional leaders and faculty members on working time patterns in research universities in different national settings.

\section{Data and methods}

The data for this study comes from the Changing Nature of the Academic Profession (CAP) project, an international survey of faculty members conducted in 2007/2008. We distinguish between countries in four culturally different regions: English language region (Australia, Canada, UK, USA); Western Europe (Finland, Germany, Italy, Norway); Asia (China, Hong Kong, Malaysia); and Latin America (Argentina, Brazil).

\section{The sample}

The sample is confined to 13 countries in which the quality of working time data holds a sufficient level for our analysis. To ensure all included respondents are employed in combined teaching and research positions at research universities, we excluded all staff employed in teaching focused universities, all staff classified as researchers, those without at least one hour per week on both teaching and research activities, all respondents without full-time contracts, and those who reported fewer than 30 hours per week.

The response rates were mostly below 40 percent. Non-respondents may differ from respondents in their research profile and there is a risk of non-response bias in the sample. While the national samples were found to be broadly representative of the respective populations on strata such as gender, academic rank and institutional type, full professors were overrepresented in most samples. Therefore, we weight the national samples based on academic rank. We classified respondents into five academic fields based on the UNESCO guidelines (1978). Details of the national samples by academic field, the size of the sub-sample used in our study and survey response rates, are listed in Table 1.

[Table 1 here]

\section{Time use: measurement and methodological challenges}

The CAP survey asked academic staff to report the number of hours they typically spend per week across five categories of tasks: teaching, research, service, administration, and other academic activities. Staff members reported these estimates for two separate time periods: when classes are in session and not in session. The survey question is reproduced in Table 2.

[Table 2 here]

Self-reported measures of working time raise, however, several methodological problems. Firstly, self-estimates of typical working hours are subject to errors of recall. When compared to diarykeeping records, which arguably offer a more accurate measure of actual working hours, selfreports have been found to over-represent working time for persons reporting the longest hours and under-represent actual hours for those reporting the shortest hours (Robinson and Bostrom 1994). In addition, flexible work schedules may negatively affect the accuracy of self-reported data when compared to actual working hours.

However, Jacobs (1998) compared self-reports to documented arrival and departure times at work and found no systematic bias based on job attributes (e.g. flexibility) or personal attributes (e.g. stress and family responsibilities). Self-reports of extremely long or short working hours did, on 
average, differ more from arrival and departure times, but this is due to "regression from the mean" rather than systemic bias. As both methods of working time measurement are subject to random error (and therefore not perfectly correlated), predicting actual hours from self-reported hours (and vice versa) will always be subject to greater error at the upper and lower extremes. Given the professional autonomy academics have beyond teaching and administrative hours, selfreports seem appropriate when estimating typical working hours in academia. However, as we are interested in examining typical working hours for full-time employees only, it is important to minimize the influence of outliers at the upper end of the measure. Therefore, we place an upper limit of weekly working time at 70 hours and recode outliers accordingly.

The second methodological problem is the overlapping nature of academic duties. Background reading is often undertaken without knowing whether it will ultimately contribute predominantly to teaching or research. Time spent advising students is defined as a teaching duty in the CAP survey, but Kyvik and Smeby (1994) found that close to 50 percent of faculty members regarded supervision of PhD students as benefiting their own research "to a great extent", though this varied between approximately 20 percent in the humanities and social sciences and about 60 percent in the natural sciences, medicine and technology. This indicates that academics from different fields may define the same tasks differently. Research funding applications and the administration of research projects also overlap research or administration. The problem of separating different work activities into the specific categories of tasks given in the questionnaire is a methodological challenge. Still, we assume that there is some general understanding across countries of what is meant by teaching, research and administration, which are the central activities. However, the notion of "service" to society is a fundamentally North-American concept (Ward 2003) and may be confused with service to the government of the nation state in countries with traditions of nationalized universities (Scott 2006). Even though "service” was defined in the questionnaire, respondents may differ in which activities they include in this category.

A third methodological problem is generalizing typical weekly hours for teaching and nonteaching periods, and across the entire year. A frequently stated barrier to research is a lack of uninterrupted time. Flexible practices allow the faculty to focus teaching loads in parts of the academic year, while freeing up time for concentrated research in others. The number of teaching semesters can also vary between universities. For example, most American universities conform to the standard two 14 to 17 week teaching semesters, but others use three 10 week "quarters" for teaching. Therefore, while teaching periods roughly cover 30 of the 46 to 47 weeks of a working year, some faculty members will negotiate longer non-teaching periods by concentrating teaching in certain teaching periods. Teaching loads can also vary across years, as academics may benefit from sabbatical or other leave entitlements from teaching duties. We annualize weekly hours by combining estimates for teaching and non-teaching periods, assuming classes are in session for two thirds of the academic year.

Finally, the CAP survey uses an inclusive definition of working time, including tasks which go beyond what would be considered working time in broader labor force surveys. For example, unpaid voluntary service to the community may be strictly at the discretion of the individual and not included as working time in other professions. Bellas and Toutkoushian (1999) show evidence that the often reported 50 hour average working week in academia is partly due to the inclusion of unpaid overtime or professional commitments outside the institution. Norwegian surveys indicate that academic staff use about 5 hours per week for unpaid or paid work external to the university (Kyvik 2000). Massy and Zemsky (1994) argue that the American faculty have increased their discretionary time available for research and the pursuit of personal goals, and loosened their institutional responsibilities to teaching. However, Jacobs and Winslow (2004) emphasize that American faculty across all institutional types (teaching or research-focused) face pressures to 
keep up to date with disciplinary research outside regular and paid working hours. Overall, faculty will differ in the extent that their working time is discretionary and this could have implications for comparisons across institutions, academic ranks and countries.

\section{Tests of significance and regional weightings}

When making pairwise comparisons, such as between professors and lower ranked staff, we adopt an independent samples $t$-test with a 95 percent significance level. For multiple pairwise comparisons, comparisons between each of the 13 countries, we use a one-way ANOVA GamesHowell multiple comparisons test with a 95 percent significance level. This choice is justified based on the unequal group sizes and variances in working hours. The Games-Howell test is preferable under such sub-optimal conditions as it maintains robust significance levels (Jaccard et al. 1984). Given the differences in country sample sizes, countries are weighted equally in regional and total (all countries) mean and standard deviation calculations.

\section{Results}

Full-time faculty at universities across all countries worked 48.4 hours per week during the teaching semester. The working week during the teaching semester was longest in the Englishspeaking countries (50.1), followed by Asia (49.7), Western Europe (48.3) and Latin America (45.4). Roughly one fifth of the faculty reported 60 hours or more per week during the teaching semester. Total working hours were significantly longer in Hong Kong (52.8), USA (51.4), Canada (51.1) and Germany (50.2), compared to Finland (47.2), Italy (46.9), Malaysia (46.3), Brazil (45.7) and Argentina (45.2). Our less restrictive definition of full-time faculty (minimum 30 hours per week) and maximum limit of 70 hours per week, gives a slightly shorter average working week than some previous studies of the academic profession (Jacobs and Winslow 2004). However, when using comparable restrictions (minimum 35 hours per week, no maximum hours), our results indicate a working week of 50.5 hours across all countries. Table 3 shows the typical weekly working hours of faculty during the teaching semester across the 13 countries.

[Table 3 here]

When classes are in session, working time across all countries was divided between duties as follows: teaching (40 percent), research (32 percent), administration (14 percent), service (7 percent), and other academic activities (6 percent). However, there are significant differences between countries in the time spent on each of the five academic activities. The number of hours spent on research differs significantly across most countries and is particularly low in Malaysia, while teaching hours are somewhat more common. Working time patterns in Western Europe and Latin America are remarkably diverse during the teaching period, suggesting that faculty members share little in common with their geographical counterparts in their teaching, research and administrative workloads.

During the non-teaching period, faculty reduce their working time, on average, by 3.7 hours per week and divide their time between duties as follows: teaching (17 percent), research (53 percent), administration (15 percent), service (8 percent), and other academic activities ( 7 percent). As a proportion of total hours, they continue to spend about 70 percent of their time on teaching and research, but time allocations shift away from teaching and towards research. Teaching consumes less than half as much time while classes are not in session, while research increases to a majority of all working hours. However, even during the non-teaching periods there are significant differences across countries and regions in working time allocations. Faculty members in Brazil increase their already modest research hours during the teaching period only marginally when 
classes are not in session, while in Malaysia they continue to spend the fewest hours on research. This is in contrast to countries such as Finland, Norway, Canada and Hong Kong, where comparably high teaching hours during the teaching period are substituted for research during the non-teaching period. Table 4 shows the typical weekly working hours of faculty across the 13 countries when classes are not in session.

[Table 4 here]

Assuming classes are in session for two thirds of a year, full-time academics across all countries worked roughly 47 hours per week across the entire year. Longest hours are found in the English speaking countries (49.1) and Asia (49.0), followed by Western European (47.6) and Latin American countries (43.0). The faculty in Hong Kong worked the longest hours per week (52.2), significantly more than all other countries. By contrast, in Brazil they worked the fewest hours (42.4), significantly fewer than all other countries except Argentina. Across the entire year, working time across all countries was divided between duties as follows: teaching (33 percent), research (39 percent), administration (15 percent), service (7 percent), and other academic activities (6 percent). The annualized working time patterns of faculty across the 13 countries are indicated in Table 5.

[Table 5 here]

Annualizing the working time patterns across the entire year provides a more accurate representation of working hours across countries, but large differences remain evident across countries and within regions. Comparing the balance of working hours between the core duties of teaching and research, Finland and Malaysia are unique in their heavier dedication of time towards teaching. The faculty in Australia, UK, Norway and Brazil divide their time roughly equally between the two activities. In Canada, USA and Hong Kong they spend more time on research than teaching, but research hours are greatest in China, Italy, Argentina and Germany, the countries with the shortest administration hours. Service is a relatively minor activity for faculty in most countries, but occupies a reasonably large share of working time in USA (11 percent) and Germany (13 percent). The longer hours dedicated to service is consistent with the deep historical significance of faculty service in both countries. However, faculty service has very different historical meanings. In an American context, faculty service traditionally involves "service to the public", "civic engagement" and "democratization", while in a German context, where academics are public sector employees, service has traditionally involved "service to the state" (Scott 2006).

Expansion of student numbers relative to staff is a global phenomenon, but the extremely short teaching hours in Argentina would suggest that this trend has affected the Argentine faculty differently. University student enrolment in Argentina approximately doubled from 1980 to 1990, and again from 1990 to 2000 (Marquina and Lamarra 2008, 365). While the Argentine faculty appear unique in their significantly fewer teaching hours (11.9), overall teaching loads within Argentine universities may not differ from countries as greatly as the data for full-time faculty suggests. Part-time teaching faculty are not included in the sample, but part-time employees influence the working time patterns of full-time faculty. Full-time faculty account for 13 percent of the teaching staff in Argentine universities and their extensive role as auxiliary teachers clearly reduces the teaching loads and interests of full-time faculty (Marquina and Lamarra 2008, 368). Variation in the use of part-time teachers across countries thus is a considerable problem in the interpretation of national differences between full-time faculty members.

The differences in working time patterns across countries are partly due to differences in the relative interests of the faculty towards research and teaching. Those who declared a relatively stronger interest in research, reported on average eight extra hours per week on research than those 
whose interests lied in teaching (21.7 vs 13.7), and four fewer hours per week on teaching (14.5 vs 18.2). Faculty members most frequently reported a stronger interest in research in Italy (79 percent), Norway (79), Germany (74) and the UK (72), and least frequently in Malaysia (54), USA (54) and China (56). However, the strength of the relationship between declared interests and research hours is skewed by USA, UK and Australia, where working time patterns appear to be more flexible. Faculty members with research interests in these countries spend roughly twice as many hours on research and 25 percent fewer hours teaching. Research interests have the weakest relationship with research and teaching hours in Brazil, Italy and Malaysia. Faculty with declared research interests in these countries spend roughly a third more hours on research and just over ten percent fewer hours on teaching.

While faculty differ greatly across countries in their working time patterns and relative interests in teaching and research, full professors are relatively similar across most countries. Professors declared a stronger interest in research over teaching compared to other faculty members (78 vs. 65 percent) and the differences were significant in Australia (93 vs. 62), China (69 vs. 53), Finland ( 85 vs. 59 ), Germany (81 vs. 73 ), Hong Kong (83 vs. 63), Italy (82 vs. 77 ), Malaysia (69 vs. 52 ), Norway ( 89 vs. 68 ), UK (95 vs. 68 ) and USA (63 vs. 50). Brazil was the only country where professors were significantly less likely to report a stronger interest in research (48 vs. 66). The generally stronger interest in research amongst professors translates into shorter teaching hours than lower ranked staff, but only slightly longer research hours. The working time patterns for professors only are shown in Table 6.

\section{[Table 6 here]}

Professors reported 49.4 hours per week across the entire year and divided their time between duties as follows: teaching (28 percent), research (39 percent), administration (19 percent), service (7 percent), and other academic activities (7 percent). Compared to other faculty members within their country, professors spent significantly fewer hours on teaching in all English-speaking and Asian countries, plus Finland and Norway. No significant differences between professors and other staff in teaching hours are found in Latin America or Italy. German professors were unique in reporting significantly more hours teaching than lower ranked staff.

The relationship between higher academic rank and teaching hours appears to be negative in most countries, but professor teaching hours vary significantly across countries and within the Englishspeaking region. The standard deviations in teaching hours are high relative to their means, particularly in Australia, UK and Malaysia where teaching appears to be a comparably minor duty for professors. Comparably less variation in teaching hours is found amongst professors in Norway, where professor teaching hours are longest. Professors in Western Europe appear to share common teaching loads of between 15 and 16 hours per week, but the differences in total working hours indicate that the relative requirements of teaching compared to other duties varies within this region.

The generally fewer teaching hours of professors does not necessarily translate directly into significantly longer research hours for professors compared to lower ranked colleagues. Professors report significantly more research hours than lower ranked academics in Australia, UK, USA, Norway and China, but the opposite is the case for professors in Argentina and Brazil where professors report significantly fewer hours on research. Differences are insignificant in the remaining countries. Tests of significance between professors and lower ranked academics within each country are affected by the smaller sample size of professors, but Italy is a particularly interesting case. Despite a very large sample size, there are no significant differences between Italian professors and other Italian faculty members in teaching or research hours. 
Despite the generally stronger interests of professors towards research, we can safely reject the null hypothesis that there are no differences across countries. However, this does not mean that differences are significant between all 13 countries; research hours are clustered around 20 hours per week in most countries. If we exclude the three countries in which professors differ most greatly from the others - Malaysia, Brazil and China - many of the differences in research hours amongst professors in the remaining 10 countries are insignificant.

Administration is perhaps the key activity that distinguishes professors from other academics in their working time patterns. Professors dedicated significantly more hours towards administration than lower ranked colleagues in all countries except UK, Malaysia and Brazil, where the relationship was positive but not significant. While there are numerous significant differences across countries in the mean administration hours of professors, this may be related to differences in teaching hours. Administration hours are longest for professors in the countries where teaching hours tend to be shortest, such as Australia, Hong Kong, UK and Malaysia. Hours dedicated to teaching and administration are perhaps less likely to be at the discretion of individual professors, resulting in a trade-off between the two institutionally directed activities.

Differences across countries in academic time use can also be attributed to national differences in the proportion of staff across academic field. To examine whether national differences in working time patterns remain after controlling for academic field, Table 7 lists the results of linear multiple regression for the working time variables, using the USA and social sciences as the reference categories (due to their median levels on most working time variables). Academic rank is not included as an independent variable as the proportion of full professors predominantly affects distribution of working time within countries, not between them. The regression results show that academic field, particularly being located in medicine, strongly affects on the number of hours spent on each of the academic duties. For example, after controlling for country, academics in medicine typically report 5.6 extra hours per week on service, 3.5 fewer hours on teaching and 1.4 fewer hours on research, compared to academics in the social sciences. Research hours are also greater in the natural sciences, while teaching hours are greater in the humanities.

[Table 7 here]

Despite the strong academic field differences, the regression results also indicate that most of the national and regional differences remain consistent and strong in their effects on time use. After controlling for academic field, total working hours and teaching hours do not differ significantly within the English-language region. Faculty in Germany and China also do not differ in the total working hours from their USA colleagues in similar academic fields, but the distribution of working hours more heavily favors research in these countries, along with Italy, Argentina and Canada. Administration hours remain significantly longer in the UK, Malaysia and Australia, compared to China, Brazil, Argentina and most Western European countries. Compared to the USA, service hours remain significantly shorter in all other countries, except Germany where academics typically report one extra hour per week than their American colleagues on this duty. Therefore, the greater service orientation of academics in Germany and the USA can not be attributed to national differences in the proportion of academics in fields of science where professional service is more common, such as medicine. Overall, the regression results confirm that national differences in total working hours and the distribution of time between tasks are significant, with very large differences in working time patterns between the USA and Germany, China and Argentina. 


\section{Discussion}

According to Meyer et al. (2007), universities are no longer shaped by nationalist agendas, "we are once again in a transnational or global era and this should lead to a narrowing of organizational differences across universities within and between countries" (Meyer et al. 2007, 211). The world dominance of the twentieth century American multifunctional university or "multiversity" is now being replaced by an internationalization model for competing in the global market and serve world-wide-stakeholders (Scott 2006). Academic credibility is increasingly defined in global terms through standardized university rankings, which promote vertical segregation and discourage specialization or diversity in university mission (Marginson 2000, 2007).

The first objective of this study was to investigate whether the spread of these images translates into similar day-to-day academic duties. We hypothesized that institutional isomorphism would underpin increasingly common working time patterns of full-time faculty at research universities in our 13 country sample, with few differences between faculty in the USA and other countries due to the hegemonic position of American research universities. Overall, our data does not support such conclusions. Faculty vary greatly within and between countries in their total working hours and distribution across tasks. On each of the three core academic duties - teaching, research and administration - we noticed large differences in the mean number of hours faculty members dedicate to each activity. Teaching hours varied least across countries, with full-time faculty reporting 16 to 17 hours per week on teaching in 10 of the 13 countries. With the exception of Germany and Argentina, where research received a clear precedence over teaching, research universities in most countries share a common engagement in teaching from their full-time faculty in similar academic fields. However, the large variation in research and administration hours indicated significant national diversity in working hours, with weak support for convergence across countries towards a common working time practice.

National differences in working time patterns are likely due to a combination of differences in institutional expectations, professional norms and the proportion of faculty by academic field. For example, the proportion of faculty within the natural sciences was highest in China, Argentina, Italy and Germany, the countries where research hours were longest. However, after controlling for academic field in our regression analyses, the effect of being located in such countries remained positive and significant as a predictor of research hours (see Table 7). This suggests that national differences extend beyond traditional disciplinary differences in research expectations. The greater time dedicated to research in these countries is probably also related to a substitution of working hours towards research due to lighter administrative loads or stronger resistance of administrative oversight, rather than a greater preference towards research over teaching or university policies promoting the recruitment of research focused staff.

The cultural hegemony of universities in the English-speaking region in the spread of ideas for best practices underpinned our second hypothesis, that working time patterns would be most similar within the English-speaking region and between other countries culturally close to the English-speaking world. There was some support for this in the data, but many conflicting results. The faculty in English-speaking countries differed less from each other than from most countries in other regions. After controlling for the relatively small differences in the proportion of staff by academic field between English-speaking countries, total working hours and teaching hours were roughly comparable. Another distinguishing feature of the English-speaking region was the relatively heavy administrative load. However, the balance between research, administration and service duties suggested greater commonality between two pairs of countries, Australia and UK, and to a lesser extent, USA and Canada. Administrative hours were significantly longer in Australia and UK, which partly accounted for the shorter research hours compared to Canada and 
service hours in the USA. This diversity may be due to the different traditions of higher education governance within the English-speaking region.

Higher education in all countries has expanded with increasing student numbers and pressures to redefine the relationship between universities, the state, and the market. Research universities occupying the top stratum of research reputation, characterized by Morhman et al. (2008) as the carriers of an Emerging Global Model, are inherently expensive to fund. Universities have traditionally looked to the state for funding, but the restructuring of universities, particularly within the English-speaking region, has been in accordance with broader neo-liberal arguments for efficiency, public accountability and organizational best practices. Hood (1995, 99-100) identified the UK, Australia, Canada and Hong Kong, and to a lesser extent USA and Norway, as countries where new public management was more eagerly adopted. Australian and British universities have implemented such principles extensively in response to calls for greater accountability from both the state and university administration (Barry et al. 2003; Lafferty and Fleming 2000), which is probably reflected in their extremely long administration hours even compared to the USA.

Faculty in Hong Kong and Norway share the most in common with their counterparts in the English-speaking region. Compared to faculty in similar academic fields in the USA, Norwegian faculty spent significantly more hours on teaching and Hong Kong faculty spent significantly more hours on research, but both countries share an equally high level of administration hours. Hong Kong, a British colony until 1997, has also extensively rationalized its higher education funding system by introducing research assessment exercises based upon the British model of linking university funding with research quality and quantity (Mok 1999). Norway was also an early adopter of new public management (Hood 1995). The deeper implementation of government systems for accountability in these countries may be reflected in the relatively long hours spent on administration.

By contrast, new public management was not eagerly adopted in Germany (Hood 1995). Italian universities have also successfully resisted outside influence and calls for greater accountability (Rostan 2008). The autonomy of universities in these countries from government and the market may partly explain the very low levels of administration and their associated impacts on research time. However, Malaysia also differed significantly from the USA with high levels of administration, matching those found in the UK and Australia. Malaysia was a particularly unique case, with extremely low levels of research time, which can not be easily explained by university restructuring based on neoliberal policies and call for increased accountability. Lee (2004) argues that Malaysian higher education is an example of relative autonomy within a globalised context, challenging the notions of cultural diffusion and institutional isomorphism.

The more similar working time patterns and heavier administration burdens of faculty in countries with stronger traditions of new public management (controlling for academic field), provides conflicting evidence regarding the appropriateness of the institutionalism framework offered by Meyer et al. (2007). While research universities in different countries face similar pressures to diversify their funding bases, even within the English-speaking region universities differ in the extent to which they are reliant on government funding and have ties with industry partners. In other words, we contend that the role of national government and governance practices affects faculty time use, in addition to professional norms regarding faculty work which may be more global in orientation.

For example, governments around the world have encouraged collaborative partnerships between universities, industry and the state. Such practices have been conceptualized as a "triple helix" approach to innovation, but national traditions shape innovation policy and its effect on 
universities (Etzkowitz et al. 2007). China and some countries in Europe and Latin America maintain a statist-driven "Triple Helix I" model, whereby the state encompasses and directs universities and industry. English-speaking counties are typically considered laissez-faire or "Triple Helix II" in their approach, whereby cooperation and competition are linked through the market. However, even within the English-speaking region the level of government centralization is greater in the UK and Australia, where national competitive research funding can be implemented through market mechanisms. This is a considerable problem when interpreting our results because the boundaries between time spent on research funding applications, administration duties associated with government funding accountability or service to funding providers, may be shaped by national culture. Therefore, the university practices for shaping faculty working time in the USA, where service occupies a significant proportion of faculty time, may reflect historical traditions of applied research and private donations, and such traditions may influence how faculty categorize their working time.

While we find significant diversity amongst full-time faculty, Meyer et al. (2007) argue that the meaning of the category "professor" has a very substantial historical and global standing, and may be shaped locally in only minor ways. The professionalized structure of the academic career involves socialization of codes of conduct and patterns of working time, which are then mimicked and reinforced through the academic reward system (Milem et al. 2000). If universities compete vis-à-vis all others on standardized global scales and universities are purposefully managed, professors likely reflect and project the desired behaviors of their institution, supporting "normative isomorphism" at the highest rank (DiMaggio and Powell 1983). Therefore, our third hypothesis was that the working time patterns of full professors are relatively similar across countries.

The results for professors indicated that similar working time patterns existed within the Englishspeaking region, and to a lesser extent in Western Europe, but Asia and Latin America were characterized by significant variation. Research is the key activity that unites professors across most countries. Compared to the broader category of full-time academics, professors are distinguished by a significantly stronger interest in research over teaching, particularly in the English-speaking region. While Western European professors also declared stronger research interests, professorial teaching hours were comparably longer in this region. Unique to Germany, professors reported significantly longer teaching hours than lower ranked academics. Professors in the two Latin American countries shared little in common with each other. Professors in Argentina shared similar working time patterns to professors in the English-speaking region, but research interests and hours were very low among professors in Brazil.

However, a mutual dedication by professors towards research does not imply common institutional expectations for the role of teacher or administrative leader. The comparably heavy administration burden and short teaching hours for professors in the English-speaking region is related to the relative number of full professors and academic hierarchy. Professors comprise roughly 10 percent of all full-time faculty members in Australia, UK, Hong Kong and Malaysia. The hierarchy is also reflected in the perceived top-down management style, with a large majority of academics in Australia (78 percent), Hong Kong (76), UK (73) and USA (65) agreeing with the statement: "At my institution there is a top-down management style”. In Australia and USA, where faculty numbers have grown at the "margins", the requirements of faculty governance and curriculum development fall increasingly to the existing base of full-time staff (Jacobs 2004; Marginson 2000). A steeper hierarchy may allow professors to delegate teaching duties and maintain their research focus, but administrative hours typically grow where professors are relative scarce due to the fact that fewer professors have to share duties as academic managers. 
By comparison, in Norway only a minority (30 percent) agreed that the management style was topdown. Barriers to promotion are also minor, with associate professors entitled to become full professors provided they are found competent (Olsen, Kyvik, and Hovdhaugen 2005).

Consequently, close to 50 percent of the Norwegian faculty are full professors. However, being a full professor in Norway does not entail the very few teaching hours or heavy administration loads of the English speaking region because duties are distributed more equitably across ranks and responsibilities of faculty governance can be divided among a greater number of professors.

Higher education systems around the world have undergone transformations away from publiclyfunded collegial communities and towards more privately-funded and managed enterprises (Enders and Musselin 2008). The strong commitment of professors towards research in most countries indicates relative consistency in working time patterns at higher ranks, with teaching responsibilities typically giving way to administration in countries with more hierarchic career structures. However, the results do not suggest that marketization and internationalization of the academic profession has led towards convergence in working time patterns across countries for non-professorial faculty. Our results show significant differences across countries which suggest conditions of academic work remain heavily dependent on national higher education traditions and patterns of workplace relations. Internationalization may quicken the transfer of successful higher education models, but implementation generally involves adaptation to the practicalities of local circumstances and traditions (Jones 1992). Even within the English-speaking world the spread of managerial practices has been implemented partially and unevenly, with core full-time faculty being in stronger position to resist intervention compared to lower ranked, part-time and newly hired faculty (Lafferty and Fleming 2000, Marginson 2000). Therefore, institutional isomorphism in how universities strategically manage faculty working time likely occurs in conjunction with diversification and specialization, with increasingly fewer faculty engaged equally in teaching and research.

\section{References}

Altbach, P. G. (1996). The international academic profession: Portraits of fourteen countries. San Francisco: Jossey-Bass Publishers.

Barry, J., Berg, E., \& Chandler, J. (2003). Managing intellectual labour in Sweden and England. Cross Cultural Management: An International Journal, 10(3), 3-22.

Bellas, M. L., \& Toutkoushian, R. K. (1999). Faculty time allocations and research productivity: Gender, race, and family effects. Review of Higher Education, 22, 367-390.

Blackburn, R. T., \& Lawrence, J. H. (1995). Faculty at Work. Motivation, Expectation, Satisfaction. Baltimore: Johns Hopkins University Press.

Clark, B. R. (1983). The higher education system. Berkeley: University of California Press.

DiMaggio, P. J., \& Powell, W. W. (1983). The iron cage revisited: Institutional isomorphism and collective rationality in organizational fields. American Sociological Review, 48(2), 147-160.

Enders, J., \& Musselin, C. (2008). Back to the future? The academic professions in the 21st century. In Higher Education to 2030: Demography (Vol. 1, pp. 125-150). Paris: OECD. 
Enders, J., \& Teichler, U. (1997). A victim of their own success? Employment and working conditions of academic staff in comparative perspective. Higher Education, 34(3), 347-372.

Etzkowitz, H., Dzisah, J., Ranga, M., \& Zhou, C. (2007). The Triple Helix Model for Innovation: The University-industry-government interaction. Asia Pacific Tech Monitor, 24(1), 14-23.

Fairweather, J. S. 1996. Faculty Work and Public Trust. Restoring the Value of Teaching and Public Service in American Academic Life. Boston: Allyn and Bacon.

Finkelstein, M. J. 1984. The American Academic Profession: A Synthesis of Social Scientific Inquiry since World War II. Columbus: Ohio State University Press.

Hood, C. (1995). The "new public management" in the 1980s: Variations on a theme. Accounting Organisations and Society, 20, 93-109.

Jaccard, J., Becker, M. A., \& Wood, G. (1984). Pairwise multiple comparison procedures: A review. Psychological Bulletin, 96(3), 589-596.

Jacobs, J. A. (1998). Measuring time at work: are self-reports accurate? Monthly Labor Review, 121(12), 42-53.

Jacobs, J. A. (2004). The faculty time divide. Sociological Forum, 19(1), 3-27.

Jacobs, J. A., \& Winslow, S. E. (2004). The academic life course, time pressures and gender inequality. Community, Work \& Family, 7(2), 143-161.

Jones, D. R. (1992). National Models of Higher Education: International Transfer. In G. Neave \& B. R. Clark (Eds.), Encyclopedia of Higher Education (Vol. 2, pp. 956-969). Oxford: Pergamon.

Kyvik, S. (2000). Academic work in Norwegian higher education. In M. Tight (Ed.), Academic Work and Life: What It Is to Be an Academic, and How This Is Changing (pp. 33-72). Amsterdam: Elsevier Science.

Kyvik, S., \& Smeby, J.C. (1994). Teaching and research. The relationship between the supervision of graduate students and faculty research performance. Higher Education, 28(2), 227-239.

Lafferty, G., \& Fleming, J. (2000). The Restructuring of Academic Work in Australia: Power, Management and Gender. British Journal of Sociology of Education, 21(2), 257-267.

Lee, M. N. N. (2003). The academic profession in Malaysia and Singapore: between bureaucratic and corporate cultures. In P. G. Altbach (Ed.), The decline of the guru: the academic profession in the third world (pp. 135-166). Chestnut Hill: Boston College..

Lee, M. N. N. (2004). Global trends, national policies and institutional responses: Restructuring higher education in Malaysia. Educational Research for Policy and Practice, 3(1), 31-46.

Marginson, S. (2000). Rethinking academic work in the global era. Journal of Higher Education Policy and Management, 22(1), 23-35.

Marginson, S. (2007). University mission and identity for a post post-public era. Higher Education Research \& Development, 26(1), 117-131. 
Massy, W. F., \& Zemsky, R. (1994). Faculty discretionary time: Departments and the "academic ratchet". Journal of Higher Education, 65(1), 1-22.

Meyer, J. W., Ramirez, F. O., Frank, D. J., \& Schofer, E. (2007). Higher Education as an Institution. In P. J. Gumport (Ed.), Sociology of higher education: Contributions and their contexts (pp. 187-221). Baltimore: John Hopkins University Press.

Milem, J. F., Berger, J. B., \& Dey, E. L. (2000). Faculty time allocation: A study of change over twenty years. Journal of Higher Education, 71(4), 454-475.

Mok, K.-H. (1999). The cost of managerialism: the implications for the 'McDonaldisation'of higher education in Hong Kong. Journal of Higher Education Policy and Management, 21(1), $117-127$

Mohrman, K., Ma, W., \& Baker, D. (2008). The Research University in Transition: The Emerging Global Model. Higher Education Policy, 21(1), 5-27.

Olsen, T. B., Kyvik, S., \& Hovdhaugen, E. (2005). The Promotion to Full Professor-Through Competition or by Individual Competence? Tertiary Education and Management, 11(4), 299-316.

Research Institute for Higher Education (RIHE) (2008) Changing Academic Profession in International Comparative and Quantitative Perspectives, Report of the International Conference on the Changing Academic Profession Project, RIHE International Seminar Reports No.12, September 2008. Hiroshima: RIHE Hiroshima University.

Robinson, J. P., \& Bostrom, A. (1994). The Overestimated Workweek? What Time Diary Measures Suggest. Monthly Labor Review, 111(8), 11-23.

Scott, J. C. (2006). The mission of the university: Medieval to postmodern transformations. Journal of Higher Education, 77(1), 1-39.

Schofer, E., \& Meyer, J. W. (2005). The worldwide expansion of higher education in the twentieth century. American Sociological Review, 70(6), 898-920.

Schuster, J. H., \& Finkelstein, M. J. (2006). The American faculty: The restructuring of academic work and careers. Baltimore: Johns Hopkins University Press.

Slaughter, S., \& Leslie, L. L. (1997). Academic Capitalism: Politics, Policies, and the Entrepreneurial University. Baltimore: The Johns Hopkins University Press.

UNESCO (1978) Recommendation Concerning the International Standardization of Statistics on Science and Technology. Paris: UNESCO.

Vabø, A., \& Ramberg, I. (2009). Arbeidsvilkår i norsk forskning. Oslo: NIFU STEP.

Ward, K. (2003). Faculty service roles and the scholarship of engagement. Vol. 29, ASHE-ERIC Higher Education Report. San Francisco: Jossey-Bass.

Welch, A. R. (Ed.). (2005). The professoriate: Profile of a profession. Dordrecht: Springer. 
Table 1. Proportion of faculty by academic field, sample size $(\mathrm{N})$ and response rate

\begin{tabular}{lccccccc}
\hline & $\begin{array}{c}\text { Social } \\
\text { sci. }\end{array}$ & $\begin{array}{c}\text { Humaniti } \\
\text { es }\end{array}$ & $\begin{array}{c}\text { Natural } \\
\text { sci. }\end{array}$ & $\begin{array}{c}\text { Technolo } \\
\text { gy }\end{array}$ & Medicine & (N) & $\begin{array}{c}\text { Response } \\
\text { rate }\end{array}$ \\
\hline Argentina & $17 \%$ & $12 \%$ & $39 \%$ & $21 \%$ & $11 \%$ & $(371)$ & $34 \%$ \\
Australia & $36 \%$ & $15 \%$ & $23 \%$ & $7 \%$ & $20 \%$ & $(526)$ & $25 \%$ \\
Brazil & $26 \%$ & $11 \%$ & $29 \%$ & $10 \%$ & $24 \%$ & $(261)$ & $26 \%$ \\
Canada & $37 \%$ & $17 \%$ & $23 \%$ & $8 \%$ & $15 \%$ & $(702)$ & $17 \%$ \\
China & $21 \%$ & $13 \%$ & $30 \%$ & $31 \%$ & $4 \%$ & $(429)$ & $86 \%^{\text {a }}$ \\
Finland & $33 \%$ & $20 \%$ & $20 \%$ & $12 \%$ & $15 \%$ & $(393)$ & $29 \%^{a}$ \\
Germany & $25 \%$ & $11 \%$ & $31 \%$ & $20 \%$ & $14 \%$ & $(612)$ & $32 \%^{\text {a }}$ \\
Hong Ko. & $44 \%$ & $22 \%$ & $14 \%$ & $8 \%$ & $12 \%$ & $(527)$ & $13 \%^{2}$ \\
Italy & $21 \%$ & $12 \%$ & $41 \%$ & $16 \%$ & $11 \%$ & $(1,358)$ & $35 \%$ \\
Malaysia & $24 \%$ & $8 \%$ & $23 \%$ & $35 \%$ & $10 \%$ & $(316)$ & $30 \%^{a}$ \\
Norway & $29 \%$ & $16 \%$ & $28 \%$ & $10 \%$ & $17 \%$ & $(366)$ & $36 \%$ \\
UK & $35 \%$ & $20 \%$ & $19 \%$ & $9 \%$ & $17 \%$ & $(569)$ & $15 \%{ }^{a}$ \\
USA & $37 \%$ & $21 \%$ & $19 \%$ & $9 \%$ & $13 \%$ & $(687)$ & $23 \%$ \\
\hline Total & $29 \%$ & $15 \%$ & $28 \%$ & $15 \%$ & $13 \%$ & $(7,117)$ & $28 \%$ \\
\hline
\end{tabular}

${ }^{a}$ Response rate includes a small number of universities without combined teaching and research missions, excluded from our final sub-sample.

Further national-level sampling details, see: Vabø and Ramberg (2009) (Norway) and RIHE (2008) (all other countries). 
Table 2. Considering all your professional work, how many hours do you spend in a typical week on each of the following activities? (If you are not teaching during the current academic year, please reply to the second column only.)

\begin{tabular}{|l|l|l|}
\hline $\begin{array}{l}\text { Hours per week } \\
\text { when classes are } \\
\text { in session }\end{array}$ & $\begin{array}{l}\text { Hours per week } \\
\text { when classes are } \\
\text { not in session }\end{array}$ & \\
\hline & & $\begin{array}{l}\text { Teaching (preparation of instructional materials and } \\
\text { lesson plans, classroom instruction, advising students, } \\
\text { reading and evaluating student work) }\end{array}$ \\
\hline & $\begin{array}{l}\text { Research ( reading literature, writing, conducting } \\
\text { experiments, fieldwork) }\end{array}$ \\
\hline & $\begin{array}{l}\text { Service (service to clients and/or patients, unpaid } \\
\text { consulting, public or voluntary services) }\end{array}$ \\
\hline & $\begin{array}{l}\text { Administration (committees, department meetings, } \\
\text { paperwork) }\end{array}$ \\
\hline & $\begin{array}{l}\text { Other academic activities (professional activities not } \\
\text { clearly attributable to any of the categories above) }\end{array}$ \\
\hline
\end{tabular}


Table 3. Mean weekly hours on academic activities when classes are in session, by country and region.

\begin{tabular}{llllllll}
\hline Country/Region & Teaching & Research & Admin. & Service & Other & Total & $\mathrm{N}$ \\
\hline English-speaking & $20.4^{*}$ & $14.3^{*}$ & $9.1^{*}$ & $3.2^{*}$ & $3.2^{*}$ & $50.1^{*}$ & 2484 \\
\hline Australia & 19.7 & $13.7^{*}$ & $9.7^{*}$ & $3.0^{*}$ & 3.0 & $49.2^{*}$ & 526 \\
Canada & 21.0 & $16.1^{*}$ & $7.7^{*}$ & $3.5^{*}$ & 2.9 & $51.1^{*}$ & 702 \\
UK & 20.0 & $12.6^{*}$ & $11.1^{*}$ & $1.4^{*}$ & 3.6 & $48.8^{*}$ & 569 \\
USA & 20.7 & 14.6 & $8.0^{*}$ & $5.0^{*}$ & 3.1 & $51.4^{*}$ & 687 \\
\hline Western Europe & $20.1^{*}$ & $16.3^{*}$ & $5.7^{*}$ & 3.3 & $2.9^{*}$ & $48.3^{*}$ & 2729 \\
\hline Finland & $23.4^{*}$ & $12.6^{*}$ & $6.0^{*}$ & $2.6^{*}$ & 2.6 & $47.2^{*}$ & 393 \\
Germany & $15.5^{*}$ & $20.1^{*}$ & $5.0^{*}$ & $6.1^{*}$ & $3.4^{*}$ & $50.2^{*}$ & 612 \\
Italy & $19.4^{*}$ & $18.1^{*}$ & $4.5^{*}$ & $2.5^{*}$ & $2.4^{*}$ & $46.9^{*}$ & 1358 \\
Norway & $22.0^{*}$ & $14.3^{*}$ & $7.3^{*}$ & $2.1^{*}$ & $3.3^{*}$ & 48.9 & 366 \\
\hline Asia & $20.7^{*}$ & $14.9^{*}$ & $7.8^{*}$ & $3.4^{*}$ & 3.0 & $49.7^{*}$ & 1272 \\
\hline China & 20.6 & $18.8^{*}$ & $5.4^{*}$ & 2.9 & $2.2^{*}$ & $49.9^{*}$ & 429 \\
Hong Kong & 21.7 & $15.9^{*}$ & $8.3^{*}$ & 3.6 & $3.4^{*}$ & $52.8^{*}$ & 527 \\
Malaysia & 19.7 & $10.0^{*}$ & $9.7^{*}$ & 3.7 & $3.3^{*}$ & $46.3^{*}$ & 316 \\
\hline Latin America & $17.2^{*}$ & $17.5^{*}$ & $5.4^{*}$ & $2.7^{*}$ & $2.6^{*}$ & $45.4^{*}$ & 632 \\
\hline Argentina & $14.8^{*}$ & $20.7^{*}$ & 4.6 & 2.9 & 2.2 & 45.2 & 371 \\
Brazil & $19.6^{*}$ & $14.4^{*}$ & 6.3 & 2.5 & 3.0 & 45.7 & 261 \\
\hline All countries & 19.6 & 15.7 & 7.0 & 3.2 & 2.9 & 48.4 & 7117
\end{tabular}

* ANOVA significant difference in means between given country and at least one other country within the same region, or significant difference between given region and at least one other region, $\mathrm{p}>0.05$. 
Table 4. Mean weekly hours on academic activities when classes are not in session, by country and region.

\begin{tabular}{|c|c|c|c|c|c|c|c|}
\hline Country / Region & Teaching & Research & Admin. & Service & Other & Total & $\mathrm{N}$ \\
\hline English-speaking & $7.2^{*}$ & $24.7 *$ & $8.1^{*}$ & $3.5^{*}$ & $3.6^{*}$ & $47.0 *$ & 2484 \\
\hline Australia & $8.4^{*}$ & $22.0 *$ & $9.6^{*}$ & $3.2^{*}$ & $4.1^{*}$ & 47.2 & 526 \\
\hline Canada & $5.6^{*}$ & $29.1 *$ & $6.6^{*}$ & $3.7^{*}$ & $2.8^{*}$ & $47.9 *$ & 702 \\
\hline UK & $8.3^{*}$ & $24.1 *$ & $9.6^{*}$ & $1.6^{*}$ & $4.1^{*}$ & $47.7 *$ & 569 \\
\hline USA & $6.3^{*}$ & $23.6 *$ & $6.4^{*}$ & $5.5^{*}$ & $3.2^{*}$ & $45.1^{*}$ & 687 \\
\hline Western Europe & $8.0^{*}$ & $26.2 *$ & $5.2^{*}$ & $3.5^{*}$ & $3.3^{*}$ & $46.2^{*}$ & 2729 \\
\hline Finland & $8.8^{*}$ & $24.6^{*}$ & 5.4 & $2.7^{*}$ & $2.9 *$ & $44.4^{*}$ & 393 \\
\hline Germany & $7.1^{*}$ & $27.2^{*}$ & $4.0^{*}$ & $6.4^{*}$ & $3.7 *$ & $48.5^{*}$ & 612 \\
\hline Italy & 7.7 & $28.7 *$ & $4.7^{*}$ & $2.7^{*}$ & $2.6^{*}$ & $46.4^{*}$ & 1358 \\
\hline Norway & 8.5 & $24.2^{*}$ & $6.7^{*}$ & $2.2^{*}$ & $3.9 *$ & $45.5^{*}$ & 366 \\
\hline Asia & $8.1^{*}$ & $23.7 *$ & $8.4^{*}$ & $3.9 *$ & $3.4^{*}$ & $47.5^{*}$ & 1272 \\
\hline China & 7.5 & $27.4^{*}$ & $5.9 *$ & 3.5 & $2.5^{*}$ & $46.8^{*}$ & 429 \\
\hline Hong Kong & $7.4^{*}$ & $27.2^{*}$ & $8.4^{*}$ & 4.1 & $3.8^{*}$ & $50.8^{*}$ & 527 \\
\hline Malaysia & $9.5^{*}$ & $16.5^{*}$ & $10.9 *$ & 4.2 & $3.9 *$ & $45.1^{*}$ & 316 \\
\hline Latin America & $7.2^{*}$ & $21.2 *$ & $4.5^{*}$ & $2.7^{*}$ & $2.5^{*}$ & $38.1 *$ & 632 \\
\hline Argentina & $6.3^{*}$ & $24.3^{*}$ & 4.6 & 3.0 & 2.3 & $40.4^{*}$ & 371 \\
\hline Brazil & $8.1^{*}$ & $18.2^{*}$ & 4.5 & 2.4 & 2.7 & $35.9 *$ & 261 \\
\hline All countries & 7.6 & 23.9 & 6.6 & 3.4 & 3.2 & 44.7 & 7117 \\
\hline
\end{tabular}

* ANOVA significant difference in means between given country and at least one other country within the same region, or significant difference between given region and at least one other region, $\mathrm{p}>0.05$. 
Table 5. Annualized weekly hours on academic activities, mean and standard deviation, by country and region.

\begin{tabular}{|c|c|c|c|c|c|c|c|c|}
\hline $\begin{array}{l}\text { Country / } \\
\text { Region }\end{array}$ & & Teach. & Research & Admin. & Serv. & Other & Total & $\mathrm{N}$ \\
\hline \multirow{2}{*}{$\begin{array}{l}\text { English- } \\
\text { speaking }\end{array}$} & Mean & $16.0^{*}$ & $17.7^{*}$ & $8.8^{*}$ & $3.3^{*}$ & $3.3 *$ & $49.1^{*}$ & 2484 \\
\hline & S.D. & 8.3 & 10.2 & 7.6 & 4.5 & 3.9 & 9.5 & 2484 \\
\hline \multirow[t]{2}{*}{ Australia } & Mean & 15.9 & $16.5^{*}$ & $9.7^{*}$ & $3.0^{*}$ & 3.4 & 48.5 & 526 \\
\hline & S.D. & 8.4 & 10.2 & 7.5 & 4.2 & 3.5 & 9.3 & 526 \\
\hline \multirow[t]{2}{*}{ Canada } & Mean & 15.9 & $20.4^{*}$ & $7.3^{*}$ & $3.5^{*}$ & $2.9 *$ & 50.0 & 702 \\
\hline & S.D. & 7.4 & 9.2 & 6.6 & 5.2 & 4.0 & 9.3 & 702 \\
\hline \multirow[t]{2}{*}{ UK } & Mean & 16.1 & $16.5^{*}$ & $10.6^{*}$ & $1.5^{*}$ & $3.8^{*}$ & 48.4 & 569 \\
\hline & S.D. & 9.3 & 10.2 & 8.7 & 3.1 & 4.1 & 9.2 & 569 \\
\hline \multirow[t]{2}{*}{ USA } & Mean & 15.9 & $17.6^{*}$ & $7.4^{*}$ & $5.2 *$ & 3.1 & 49.3 & 687 \\
\hline & S.D. & 8.0 & 11.0 & 7.5 & 5.5 & 3.8 & 10.2 & 687 \\
\hline Western & Mean & $16.1^{*}$ & $19.6^{*}$ & $5.6^{*}$ & 3.4 & $3.0 *$ & $47.6^{*}$ & 2729 \\
\hline Europe & S.D. & 8.2 & 9.8 & 5.3 & 6.4 & 4.1 & 8.9 & 2729 \\
\hline \multirow[t]{2}{*}{ Finland } & Mean & $18.5^{*}$ & $16.6^{*}$ & $5.8^{*}$ & $2.6^{*}$ & 2.7 & $46.3^{*}$ & 393 \\
\hline & S.D. & 9.0 & 9.0 & 5.6 & 4.3 & 3.2 & 8.3 & 393 \\
\hline \multirow[t]{2}{*}{ Germany } & Mean & $12.7^{*}$ & $22.5^{*}$ & $4.7 *$ & $6.2^{*}$ & $3.5 *$ & $49.6^{*}$ & 612 \\
\hline & S.D. & 9.2 & 11.5 & 5.6 & 10.9 & 5.0 & 9.1 & 612 \\
\hline \multirow[t]{2}{*}{ Italy } & Mean & $15.5^{*}$ & $21.6^{*}$ & $4.6^{*}$ & $2.6^{*}$ & $2.5^{*}$ & $46.7^{*}$ & 1358 \\
\hline & S.D. & 7.3 & 9.6 & 4.6 & 6.7 & 4.0 & 9.5 & 1358 \\
\hline \multirow[t]{2}{*}{ Norway } & Mean & $17.5^{*}$ & $17.6^{*}$ & $7.1^{*}$ & $2.1^{*}$ & $3.5^{*}$ & 47.8 & 366 \\
\hline & S.D. & 7.2 & 8.9 & 5.6 & 3.5 & 4.0 & 8.7 & 366 \\
\hline \multirow[t]{2}{*}{ Asia } & Mean & $16.5^{*}$ & $17.8^{*}$ & $8.0 *$ & $3.6 *$ & $3.1^{*}$ & $49.0^{*}$ & 1272 \\
\hline & S.D. & 8.6 & 9.8 & 7.8 & 5.0 & 3.7 & 11.1 & 1272 \\
\hline \multirow[t]{2}{*}{ China } & Mean & 16.3 & $21.6^{*}$ & $5.6^{*}$ & 3.1 & $2.3^{*}$ & $48.9^{*}$ & 429 \\
\hline & S.D. & 8.9 & 11.6 & 7.7 & 5.3 & 3.3 & 12.4 & 429 \\
\hline Hong & Mean & 16.9 & $19.6^{*}$ & $8.3^{*}$ & 3.7 & $3.6^{*}$ & $52.2 *$ & 527 \\
\hline Kong & S.D. & 9.2 & 10.9 & 8.0 & 4.3 & 4.3 & 9.9 & 527 \\
\hline \multirow[t]{2}{*}{ Malaysia } & Mean & 16.3 & $12.2^{*}$ & $10.1^{*}$ & 3.9 & $3.5^{*}$ & $45.9 *$ & 316 \\
\hline & S.D. & 7.7 & 6.8 & 7.8 & 5.4 & 3.5 & 11.0 & 316 \\
\hline Latin & Mean & $13.8 *$ & $18.8^{*}$ & $5.1^{*}$ & $2.7 *$ & $2.6^{*}$ & $43.0^{*}$ & 632 \\
\hline America & S.D. & 6.1 & 8.5 & 5.9 & 4.2 & 3.6 & 8.1 & 632 \\
\hline \multirow[t]{2}{*}{ Argentina } & Mean & $11.9 *$ & $21.9 *$ & 4.6 & 2.9 & 2.2 & 43.6 & 371 \\
\hline & S.D. & 4.9 & 8.3 & 6.0 & 4.1 & 3.4 & 7.2 & 371 \\
\hline \multirow[t]{2}{*}{ Brazil } & Mean & $15.8^{*}$ & $15.6^{*}$ & 5.7 & 2.4 & 2.9 & 42.4 & 261 \\
\hline & S.D. & 7.2 & 8.7 & 5.9 & 4.4 & 3.8 & 9.0 & 261 \\
\hline All & Mean & 15.6 & 18.5 & 6.9 & 3.2 & 3.0 & 47.2 & 7117 \\
\hline Countries & S.D. & 7.8 & 9.5 & 6.7 & 5.0 & 3.8 & 9.4 & 7117 \\
\hline
\end{tabular}

* ANOVA significant difference in means between given country and at least one other country within the same region, or significant difference between given region and at least one other region, $\mathrm{p}>0.05$. 
Table 6. Annualized weekly hours on academic activities, mean and standard deviation, professors only, by country and region

\begin{tabular}{|c|c|c|c|c|c|c|c|c|}
\hline Country / & & Teach. & Research & Admin. & Serv. & Other & Total & $\mathrm{N}$ \\
\hline \multirow{2}{*}{$\begin{array}{l}\text { English- } \\
\text { speaking }\end{array}$} & Mean & $12.4^{*^{+}}$ & $20.4^{*^{+}}$ & $10.3^{*^{+}}$ & $4.1^{*^{+}}$ & 3.6 & $50.8^{*^{+}}$ & 702 \\
\hline & S.D. & 7.0 & 10.3 & 9.2 & 5.6 & 4.2 & 9.5 & 702 \\
\hline \multirow[t]{2}{*}{ Australia } & Mean & $10.1^{*^{+}}$ & $21.0^{+}$ & $12.5^{+}$ & 4.6 & 4.2 & $52.4^{+}$ & 56 \\
\hline & S.D. & 6.3 & 10.5 & 11.1 & 6.7 & 4.1 & 10.4 & 56 \\
\hline \multirow[t]{2}{*}{ Canada } & Mean & $14.0^{*^{+}}$ & 20.1 & $8.7^{+}$ & 3.8 & 3.1 & 49.7 & 246 \\
\hline & S.D. & 6.7 & 9.5 & 8.1 & 5.1 & 4.6 & 8.7 & 246 \\
\hline \multirow[t]{2}{*}{ UK } & Mean & $11.6^{+}$ & $21.0^{+}$ & 11.3 & $2.6^{*^{+}}$ & 4.1 & $50.6^{+}$ & 125 \\
\hline & S.D. & 7.6 & 10.4 & 8.8 & 4.5 & 4.5 & 9.1 & 125 \\
\hline \multirow[t]{2}{*}{ USA } & Mean & $13.7^{*^{+}}$ & $19.4^{+}$ & $8.6^{+}$ & $5.5^{*}$ & 3.0 & 50.3 & 275 \\
\hline & S.D. & 7.4 & 10.7 & 8.8 & 6.3 & 3.4 & 9.6 & 275 \\
\hline Western & Mean & $15.6^{*}$ & $19.7 *$ & $8.1^{*^{+}}$ & $3.2^{*^{+}}$ & $4.0^{+}$ & $50.5^{*^{+}}$ & 912 \\
\hline Europe & S.D. & 7.1 & 9.1 & 6.2 & 5.1 & 4.7 & 8.9 & 912 \\
\hline \multirow[t]{2}{*}{ Finland } & Mean & $15.8^{+}$ & $17.5^{*}$ & $8.9 *^{+}$ & 2.9 & $3.9^{+}$ & $48.9 *^{+}$ & 151 \\
\hline & S.D. & 7.0 & 9.6 & 6.6 & 3.9 & 3.6 & 8.4 & 151 \\
\hline \multirow[t]{2}{*}{ Germany } & Mean & $15.3^{+}$ & 19.8 & $9.1 *^{+}$ & $5.2^{*^{+}}$ & $5.6^{*}$ & $54.9 *^{+}$ & 159 \\
\hline & S.D. & 7.3 & 8.1 & 6.5 & 7.4 & 6.6 & 8.8 & 159 \\
\hline \multirow[t]{2}{*}{ Italy } & Mean & 15.0 & $21.6^{*}$ & $6.3^{*^{+}}$ & $2.1^{*}$ & $2.7^{*}$ & $47.7 *^{+}$ & 400 \\
\hline & S.D. & 7.4 & 10.3 & 6.0 & 5.6 & 4.3 & 9.2 & 400 \\
\hline \multirow[t]{2}{*}{ Norway } & Mean & $16.1^{+}$ & $19.7^{+}$ & $8.0^{+}$ & $2.7^{+}$ & 3.9 & $50.4^{*^{+}}$ & 202 \\
\hline & S.D. & 6.5 & 8.6 & 5.9 & 3.6 & 4.3 & 9.0 & 202 \\
\hline \multirow[t]{2}{*}{ Asia } & Mean & $12.9^{*^{+}}$ & $19.1^{*^{+}}$ & $10.8^{*^{+}}$ & 3.7 & $4.1^{+}$ & $50.5^{*^{+}}$ & 302 \\
\hline & S.D. & 7.5 & 9.7 & 9.6 & 5.7 & 4.1 & 10.5 & 302 \\
\hline \multirow[t]{2}{*}{ China } & Mean & $14.1^{+}$ & $24.9 *^{+}$ & $6.8^{*}$ & 2.4 & $2.4^{*}$ & 50.5 & 146 \\
\hline & S.D. & 8.2 & 12.6 & 7.5 & 4.7 & 3.3 & 12.6 & 146 \\
\hline Hong & Mean & $11.9^{+}$ & $20.4^{*}$ & $12.2^{*^{+}}$ & 4.0 & $4.7^{+}$ & 53.2 & 127 \\
\hline Kong & S.D. & 6.2 & 9.3 & 9.8 & 4.4 & 5.3 & 9.2 & 127 \\
\hline \multirow[t]{2}{*}{ Malaysia } & Mean & $12.6^{+}$ & $11.9 *$ & 13.5 & 4.8 & $5.1^{*^{+}}$ & 47.9 & 29 \\
\hline & S.D. & 8.0 & 7.4 & 11.5 & 7.9 & 3.8 & 9.6 & 29 \\
\hline Latin & Mean & $13.9 *$ & $16.3^{*^{+}}$ & $7.2^{*^{+}}$ & $3.0^{*}$ & 2.8 & $43.1 *$ & 159 \\
\hline America & S.D. & 6.5 & 7.9 & 7.3 & 4.2 & 3.7 & 8.1 & 159 \\
\hline \multirow[t]{2}{*}{ Argentina } & Mean & 11.9 & $19.1^{*^{+}}$ & $7.3^{+}$ & 3.4 & 2.6 & 44.3 & 111 \\
\hline & S.D. & 4.7 & 7.5 & 7.7 & 3.9 & 3.7 & 7.2 & 111 \\
\hline \multirow[t]{2}{*}{ Brazil } & Mean & 15.9 & $13.5^{*^{+}}$ & 7.1 & 2.5 & 2.9 & 41.9 & 48 \\
\hline & S.D. & 8.2 & 8.3 & 6.9 & 4.5 & 3.8 & 9.1 & 48 \\
\hline All & Mean & 13.7 & 19.2 & 9.2 & 3.6 & 3.7 & 49.4 & 2075 \\
\hline Countries & S.D. & 7.1 & 9.4 & 8.1 & 5.3 & 4.2 & 9.3 & 2075 \\
\hline
\end{tabular}

* ANOVA significant difference in means between given country and at least one other country within the same region, or significant difference between given region and at least one other region, $\mathrm{p}>0.05$.

+ Independent samples t-test significant difference between professors and lower ranked academics within country/region, $\mathrm{p}>0.05$. 
Table 7. Linear multiple regression unstandardized beta weights for effect of country and academic field on annualized weekly hours on academic activities

\begin{tabular}{lllllll}
\hline & Teaching & Research & Admin & Service & Other & Total \\
\hline Constant & $16.37^{*}$ & $17.10^{*}$ & $7.62^{*}$ & $4.84^{*}$ & $3.33^{*}$ & $49.26^{*}$ \\
\hline Australia & 0.28 & -1.05 & $2.24^{*}$ & $-2.42^{*}$ & 0.25 & -0.70 \\
Canada & 0.17 & $2.73^{*}$ & -0.12 & $-1.70^{*}$ & -0.25 & 0.82 \\
UK & 0.38 & -1.07 & $3.16^{*}$ & $-3.96^{*}$ & $0.65^{*}$ & -0.84 \\
\hline Finland & $2.71^{*}$ & -0.95 & $-1.64^{*}$ & $-2.59^{*}$ & -0.46 & $-2.94^{*}$ \\
Germany & $-2.62^{*}$ & $4.49^{*}$ & $-2.65^{*}$ & $1.03^{*}$ & 0.39 & 0.63 \\
Italy & 0.15 & $3.26^{*}$ & $-2.69^{*}$ & $-2.34^{*}$ & $-0.59^{*}$ & $-2.21^{*}$ \\
Norway & $1.91^{*}$ & -0.18 & -0.29 & $-3.23^{*}$ & 0.39 & $-1.39^{*}$ \\
\hline China & 0.74 & $3.49^{*}$ & $-1.77^{*}$ & $-1.54^{*}$ & $-0.93^{*}$ & -0.01 \\
Hong Kong & 0.87 & $2.20^{*}$ & 0.81 & $-1.42^{*}$ & 0.41 & $2.87^{*}$ \\
Malaysia & 0.85 & $-5.63^{*}$ & $2.68^{*}$ & $-1.14^{*}$ & 0.23 & $-3.01^{*}$ \\
\hline Argentina & $-3.41^{*}$ & $3.60^{*}$ & $-2.73^{*}$ & $-1.98^{*}$ & $-0.85^{*}$ & $-5.37^{*}$ \\
Brazil & 0.42 & $-2.04^{*}$ & $-1.71^{*}$ & $-3.21^{*}$ & -0.19 & $-6.73^{*}$ \\
\hline Humanities & $1.82^{*}$ & 0.10 & 0.04 & $-0.66^{*}$ & $-0.40^{*}$ & $0.89^{*}$ \\
Natural Sciences & $-1.46^{*}$ & $3.21^{*}$ & $-0.68^{*}$ & $-1.02^{*}$ & $-0.63^{*}$ & -0.57 \\
Technology & $-1.78^{*}$ & 0.68 & -0.26 & -0.15 & $0.38^{*}$ & $-1.13^{*}$ \\
Medicine & $-3.47^{*}$ & $-1.35^{*}$ & -0.27 & $5.58^{*}$ & $-0.35^{*}$ & 0.13 \\
\hline Adjusted R-Square & 0.06 & 0.09 & 0.08 & 0.15 & 0.20 & 0.05 \\
\hline
\end{tabular}




\section{University Library}

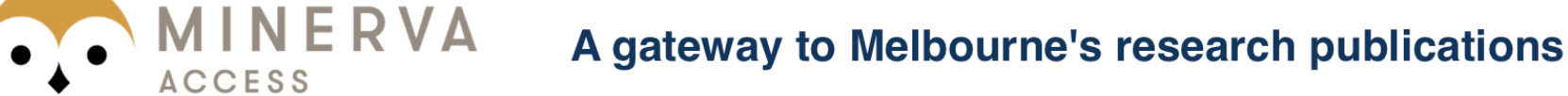

Minerva Access is the Institutional Repository of The University of Melbourne

Author/s:

Bentley, PJ;Kyvik, S

Title:

Academic work from a comparative perspective: a survey of faculty working time across 13 countries

Date:

2012-04-01

Citation:

Bentley, P. J. \& Kyvik, S. (2012). Academic work from a comparative perspective: a survey of faculty working time across 13 countries. HIGHER EDUCATION, 63 (4), pp.529-547. https://doi.org/10.1007/s10734-011-9457-4.

Persistent Link:

http://hdl.handle.net/11343/119554 